\title{
RENEWABLE ENERGY PROJECTS ASSESSMENT USING ECONOMIC CRITERIA
}

\author{
Bojan Stojčetović ${ }^{1}$ \\ ${ }^{1}$ High technical school of professional studies Zvečan, Serbia \\ Sanja Marković \\ ${ }^{2}$ High technical school of professional studies Zvečan, Serbia \\ Dejan Bogdanović 3 \\ Technical faculty in Bor, Serbia
}

\begin{abstract}
Unstable electricity supply is a major challenge for Kosovo* and especially for Serb-majority communities. Renewable energy may represent one of the possible solutions to improve the energy security of those areas. Therefore, the municipality of Strpce was selected as the research area of the paper, and it is located in the south of Kosovo*. However, renewable energy potentials have not been sufficiently explored and specific projects are not proposed. Therefore, the aim of this paper is to define renewable energy projects. Based on renewable energy potential and electricity consumption in Strpce, a set of 8 renewable energy potential projects has been defined using Homer pro software. However, the problem that arises is the choice of an adequate alternative on the basis of economic criteria. Six criteria were selected for the evaluation of renewable energy projects. To assess criteria analytical hierarchy process is employed. The highest priority was given to the criterion energy sold (0.280) while the top-ranked project is refer to installation of photovoltaic panels in households to cover 50\% of energy needs while the rest is taken from the grid (0.222). In future research, in addition to used economic criteria, other groups of criteria such as technical, environmental and socio-political should be analyzed.
\end{abstract}

Keywords: Štrpce, energy, renewable energy, analytical hierarchy process

\section{INTRODUCTION}

Safe and uninterrupted electricity supply is one of the preconditions for the development of every modern economy and society. The characteristics of modern society, reflected in population growth, urbanization and industrialization, require rethinking and redefining strategic decisions in order to meet the continued growth of energy demand (Ervural et al., 2018). The importance of energy has also been recognized by the United Nations (UN), which declared the Decade 20142024 a "Decade for Sustainable Energy for All", to ensure affordable, reliable and sustainable energy for all (UN, 2014). However, according to (International Energy Agency/IEA, 2017), as many as 1.1 billion people do not have access to electricity, although net electricity production

\footnotetext{
${ }^{1}$ bstojcetovic@gmail.com

2 sanjamark045@gmail.com

3 dnbogdanovic@yahoo.com
} 
globally increases from 21.6 (trillion $\mathrm{kWh}$ ) in 2012 to 25.8 (trillion $\mathrm{kWh}$ ) in 2020. year to 36.5 (trillion $\mathrm{kWh}$ ) in 2040 (International energy outlookIEO, 2016).

According to (REN21, 2016), the share of fossil fuels in total global energy consumption in 2014 is $78.3 \%$, nuclear energy $2.5 \%$ and the share of renewable energy sources (RES) $19.2 \%$. However, according to (IEO, 2016) RES projections are the fastest growing sources of electricity generation with an average increase of $2.9 \%$ per year between 2012. and 2040. Numerous benefits of RES can be stated. Frances et al. (2013) find that RES can contribute to risk reduction because decentralized RES capacities are less at risk of sabotage than centralized ones. RES are also safer in the case of accidents (except for large hydropower plants). Also, RES contributes to greater security through diversification of both technology and various energy sources (Lucas et al., 2016) and does not require fuel to produce electricity. In addition to being used as an energy source, RES can lead to improved energy security, environmental protection and poverty reduction (Renewable global status report, 2014). However, in order to select one of the set of available RES projects, it is most often necessary to consider a number of criteria, which indicates the need to use multi-criteria decision-making methods (MCDMs). There are numerous MCDM methods: Analytical hierarchy/network process (AHP/ANP), Preference Ranking Organization METHod for Enrichment of Evaluations (PROMETHEE), Technique for Order of Preference by Similarity to Ideal Solution (TOPSIS), etc. AHP is one of the most commonly used methods in various fields: agriculture (Milovanović et al., 2018), environment (Pasalari et al., 2019), software (Ali Khan et al., 2019). AHP is widely used in renewable energy sector (Colak et al., 2020; Konstantinos et al., 2019). Also, different sets of criteria are used to evaluate and rank RES projects: technical, environmental, socio-political and economic. Some of the most commonly used economic criteria are: investment costs (Haddad et al. 2017; Stojčetović et al. 2016), O\&M costs (Haddad et al., 2017; Al Garni et al., 2016;), electricity cost energy (Al Garni et al., 2016;), return on investment (Haddad et al., 2017;), feed-in tariffs (Ahmad et al., 2014; Stojčetović et al., 2016), operating life (Haddad et al., 2017).

One of the problems with evaluating projects (alternatives) is that science-based decision-making methods are often not used. Such an approach can lead to making wrong decisions. For that reason the goal of this paper is to define RES projects in accordance with the needs and RES potentials of the municipality of Štrpce and then to evaluate/rank them according to economic criteria using AHP method. 


\section{APPLIED METHODOLOGY}

To evaluate RES projects in this paper AHP method is employed. AHP is a multi-criteria technique that is based on decomposing a complex problem into a hierarchy of goal, criteria and alternatives (Milovanović, 2019). The AHP method was developed by Thomas Saaty (1980). At the top of the structure is the goal, followed by selected criteria on the second as well as alternatives on the third level. More complex problems may also include sub-criteria, which in this case occupy the level between the criteria and the alternatives. In order to solve the problem of hierarchical structure, AHP procedure is defined as follows (Shahabi et al., 2014):

1. Step 1: The hierarchical structure is defined so that the goal is at the top of the hierarchy while the criteria and strategies are positioned in descending order.

2. Step 2: At each level, a pairwise comparison matrix is obtained. A scale (Table 1) ranging from 1 (equal importance) to 9 (absolute importance) is used to identify the priorities of each criterion (alternative) over the other criteria (alternatives).

3. Step 3: All pairwise matrices are synthesized to calculate the relative and global weights of each criterion, sub-criterion and alternative.

Defining a hierarchy is a very important step of the AHP, although it is often not given adequate importance. The hierarchy needs to be defined in the right way, otherwise this initial step may lead to a decision that is not relevant.

To perform pairwise comparisons of all relevant criteria / alternatives, Saaty proposes to form an $n \times n$ pairwise comparison matrix A:

$$
A=\left(\begin{array}{cccc}
a_{11} & a_{12} & \cdots & a_{1 n} \\
a_{21} & a_{22} & \cdots & a_{2 n} \\
\vdots & \vdots & \ddots & \vdots \\
a_{n 1} & a_{n 2} & \cdots & a_{n n}
\end{array}\right)
$$

where by $a_{i j}$ values are obtained using the 9-point scale defined by Saaty (1980).

Table 1.: Saaty scale

\begin{tabular}{cll}
\hline Intensity & Definition & Explanation \\
\hline $\mathbf{1}$ & Equal significance & The two activities contribute equally to the goal. \\
\hline $\mathbf{3}$ & $\begin{array}{l}\text { Moderate } \\
\text { significance }\end{array}$ & $\begin{array}{l}\text { Experience and evaluation slightly favor one } \\
\text { activity over another }\end{array}$ \\
\hline $\mathbf{5}$ & Strong significance & $\begin{array}{l}\text { Experience and assessment strongly favor one } \\
\text { activity over another }\end{array}$ \\
\hline
\end{tabular}




\begin{tabular}{cll}
\hline $\mathbf{7}$ & $\begin{array}{l}\text { Very strong or } \\
\text { demonstrated } \\
\text { significance }\end{array}$ & $\begin{array}{l}\text { One activity } j \text { is strongly favored over another; its } \\
\text { dominance has been demonstrated in practice. }\end{array}$ \\
\hline $\mathbf{9}$ & Absolute significance & $\begin{array}{l}\text { Evidence favoring one activity over another is the } \\
\text { highest possible level of validation. }\end{array}$ \\
\hline $\mathbf{2 , , 4 , 6 , 8}$ & Inter-results & $\begin{array}{l}\text { They are used to make a compromise between the } \\
\text { priorities outlined above. }\end{array}$ \\
\hline
\end{tabular}

Matrix $A$ is a positive reciprocal matrix in which $a_{i j}$ represents the preference ratio of the alternative $i$ with respect to the alternative $j$. The $a_{i j}$ value is the reciprocal of the $a_{i j}$ value. That is, $a_{i j}=\frac{1}{a_{i j}}$

If the pairwise comparisons are consistent then $a_{i j}$ elements of matrix $A$ satisfy the equation:

$a_{i j} \cdot a_{j k}=a_{i k,}$ for each $i, j, k$.

Weighting factor of criteria/alternatives can be marked with $w_{i}$. If matrix $A$ is consistent $a_{i j}$ can be represented as $a_{i j}=\frac{w_{i}}{w_{j}}$ for each $i$ and $j$.

Therefore, if $A$ is consistent then:

$A * W=\left(\begin{array}{cccc}\frac{w_{1}}{w_{1}} & \frac{w_{1}}{w_{2}} & \cdots & \frac{w_{1}}{w_{n}} \\ \frac{w_{2}}{w_{1}} & \frac{w_{2}}{w_{2}} & \ldots & \frac{w_{2}}{w_{n}} \\ \vdots & \vdots & \ddots & \vdots \\ \frac{w_{n}}{w_{1}} & \frac{w_{n}}{w_{2}} & \cdots & \frac{w_{n}}{w_{n}}\end{array}\right) *\left(\begin{array}{c}w_{1} \\ w_{2} \\ \vdots \\ w_{n}\end{array}\right)=n *\left(\begin{array}{c}w_{1} \\ w_{2} \\ \vdots \\ w_{n}\end{array}\right)$

By normalizing the matrix $A=\left[a_{i j}\right]_{n x n}$ the weight factor is calculated as follows:

$a_{i j}^{*}=\frac{a_{i j}}{\sum_{i=1}^{n} a_{i j}}$

for each $j=1,2, \ldots, n$. Then:

$w_{i}=\frac{\sum_{i=1}^{n} a_{i j}}{n}$

for each $j=1,2, \ldots, n$.

To determine the level of consistency a consistency index (CI) that can be calculated according to the following equation:

$C I=\frac{(\lambda \max -n)}{(n-1)}$

Where $\lambda_{\max }$ is a parameter for validation in AHP. The closer the value of $\lambda_{\max }$ is to $n$, the more consistent the estimate is. formula:

The consistency ratio can be calculated using the following

$C R=\frac{C I}{R I}$ 
wherein RI (Random index) is a random consistency index whose values for $(\mathrm{n} \leq 10)$ are given in Table 2 .

Table 2.: Average RI values

\begin{tabular}{lllllllllll}
\hline $\mathbf{n}$ & $\mathbf{1}$ & $\mathbf{2}$ & $\mathbf{3}$ & $\mathbf{4}$ & $\mathbf{5}$ & $\mathbf{6}$ & $\mathbf{7}$ & $\mathbf{8}$ & $\mathbf{9}$ & $\mathbf{1 0}$ \\
\hline RI & 0 & 0 & 0.58 & 0.90 & 1.12 & 1.24 & 1.32 & 1.41 & 1.45 & 1.49 \\
\hline
\end{tabular}

When $C R<0.10$ the matrix can be evaluated as acceptable, otherwise, the matrix should be modified to reach an acceptable size (Ren and Sovacool, 2015).

\section{RESEARCH AREA}

Since 1999. numerous problems have been present in the Kosovo* energy sector. These are summarized by (Kosovo* Energy Strategy, 2017) as follows: delays in building new and rehabilitating existing capacities; overloading of the power system, especially during the winter; lack of natural gas infrastructure; significant losses of electricity in the distribution network; underutilization of RES potential; lack of competitive electricity market, etc.

Electricity production in Kosovo* from 2000. to 2015. increased slightly with the exception of 2014. (Figure 1). However, the growing demand is not accompanied by the construction of new capacities that would enable a sustainable and secure supply of electricity in the coming period, but the production is carried out in power plants whose working life is at the end.

Figure 1.: Electricity consumption and its structure

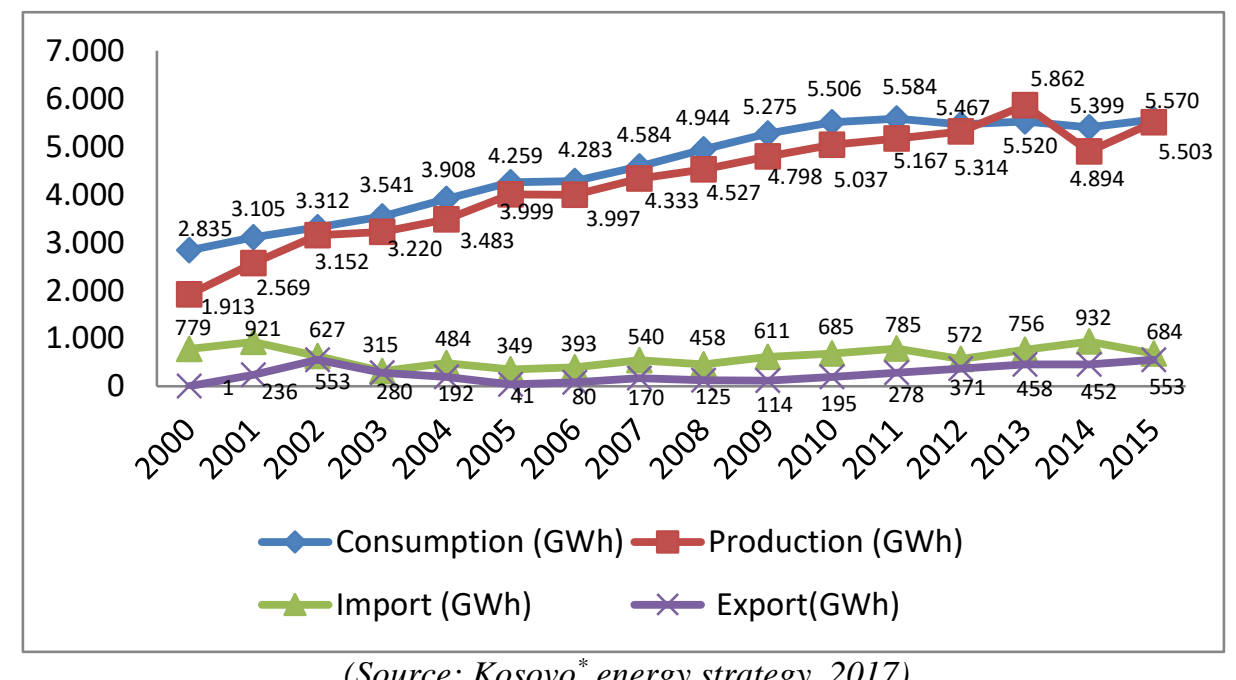

Vol. 22, бpoj 1/2020, cmp. 15-28 
The main electricity generation capacity in Kosovo* are two thermal power plants (Kosovo* A and Kosovo* B) whose operating capacity is $915 \mathrm{MW}(62 \%)$. These capacities are insufficient, outdated and inefficient, which also required significant imports of electricity, for which 538.25 million euro was spent between 2000. and 2015. (Kosovo* Energy Strategy, 2017). Lignite is used to produce 97\% of total electricity production in Kosovo* (Kosovo* Energy Strategy, 2016). Kosovo's* geological lignite reserves are estimated at around 12.5 billion tones and rank second in Europe and fifth in the world (Kosovo* Energy Strategy, 2017).

Nowadays, regular supply of electricity and various energy products is implied, at least in developed countries. However, in Kosovo*, and especially in Serb communities, electricity supply is very volatile. This problem is characteristic for almost all Serbian communities located south of the Ibar river. Of course, it must also be taken into account that in Kosovo" after the 1999. there were major problems with the production and supply of electricity throughout the territory, but it is also evident that Serbian communities were more frequently exposed to electricity restrictions. According to the survey (Stojčetović et al., 2017), as many as $45.5 \%$ of respondents completely agree with the statement that frequent restrictions represent a form of political pressure. As thermal power plants as well as the transmission network are under the control of the provisional administration of Kosovo*, it can be expected that in the future, regular supply of electricity to Štrpce will depend on the "goodwill" of the Kosovo" administration and/or current political circumstances.

The main reasons for frequent electricity restrictions in Štrpce are: insufficient electricity production in Kosovo*, transmission losses, illegal network connections, non-payment of electricity to the supplier, old transmission network, frequent network failures, political pressures. On the other hand, the question is why not to use RES for electricity production in local communities and thus increase the level of energy security? Each territory has different RES potentials and therefore adequate RES technologies for electricity generation must be selected. The municipality of Štrpce has certain potentials for biomass, solar, wind and hydro power.

Since 1999. the supply of electricity in Strpce has been problematically confirmed by the opinion of the survey respondents (Stojčetović et al., 2017), according to which $45.5 \%$ of respondents claim that the supply of electricity is very unstable with very frequent restrictions and $36.4 \%$ stated that the supply of electricity is unstable with 
frequent restrictions. Only $18.2 \%$ of the respondents stated that electricity supply in Štrpce is regular and without restrictions.

Electricity consumption in Strpce for the period from 2014. to 2017. is presented in Table 3. It should be emphasized that the mentioned consumption refers to households, public institutions and the Brezovica ski center, which consumes about 1.5 MWh for heating and cableways during the winter months. Other tourist and economic capacities have not been operational since 1999. and their reactivation is not expected in the near future. The highest consumption is during the winter months with a maximum in December and January.

Table 3.: Electricity consumption in Štrpce

\begin{tabular}{lcccc}
\cline { 1 - 4 } Year & $\mathbf{2 0 1 4}$ & $\mathbf{2 0 1 5}$ & $\mathbf{2 0 1 6}$ & $\mathbf{2 0 1 7}$ \\
\cline { 1 - 4 } Jonth & & & & \\
\hline February & 2428.1234 & 2491.0883 & 2483.0127 & 2773.6044 \\
\hline Mach & 2157.4712 & 2260.5093 & 2118.5346 & 2057.3406 \\
\hline April & 1840.9734 & 1955.4980 & 1800.9621 & 1870.3639 \\
\hline May & 1849.1036 & 1771.9033 & 1866.7477 & 1781.5581 \\
\hline June & 1603.7070 & 1451.9789 & 1682.0034 & 1614.9682 \\
\hline July & 1714.8605 & 1451.9789 & 1729.1810 & 1682.1504 \\
\hline August & 1681.6984 & 1612.9649 & 1719.4506 & 1675.5522 \\
\hline September & 1753.9448 & 1669.0821 & 1725.0492 & 1660.1088 \\
\hline October & 1716.8204 & 1881.2593 & 1916.7005 & 1871.1525 \\
\hline November & 2048.6424 & 2028.3994 & 1988.0448 & 2016.2268 \\
\hline December & 2297.3302 & 2366.8512 & 2459.3289 & 2361.6411 \\
\hline Total(MWh) & 23169.0620 & 23140.1321 & 23550.8984 & 23505.9080 \\
\hline Total(GWh) & 23.1691 & 23.1401 & 23.5509 & 23.5059 \\
\hline & (Kosovo* electricity & distribution and supply company) &
\end{tabular}

\section{RESULTS AND DISCUSSION}

In the first phase, a local energy expert used software (Homer pro) to generate initial RES alternatives. For modeling purposes, the software used data on electricity consumption in Štrpce and data on RES potentials. A total of 8 alternatives have been defined (Table 4). The goal is to select the optimal RES alternative over the defined criteria. 
Table 4.: Generated alternatives

\begin{tabular}{ll}
\hline \multicolumn{1}{c}{ No. } & \multicolumn{1}{c}{ System architecture } \\
\hline $\begin{array}{l}\text { Alternative 1 } \\
\text { (ALT1) }\end{array}$ & $\begin{array}{l}\text { PV panels (25.4 kW), 17 kW converter, 120 kWh batteries } \\
\text { (78 hours autonomy) }\end{array}$ \\
\hline $\begin{array}{l}\text { Alternative 2 } \\
\text { (ALT2) }\end{array}$ & PV panels (5 kW), converter 2.63 kW. \\
\hline $\begin{array}{l}\text { Alternative3 } \\
\text { (ALT1) }\end{array}$ & $\begin{array}{l}\text { Hydro power plant 1.2 MW, Biomass power plant 1 MW, Solar } \\
\text { power plant 1 MW, Wind power plant 1 MW, Converter 1 MW, } \\
\text { Batteries 2 MWh, 1000 new street lamps for solar energy } \\
\text { (autonomy 3.89 hours). }\end{array}$ \\
\hline $\begin{array}{l}\text { Alternative 4 } \\
\text { (ALT4) }\end{array}$ & $\begin{array}{l}\text { Hydro power plant 1.2 MW, wind power plant 1 MW, solar } \\
\text { power plant 1 MW, (RES share 81.1\%) }\end{array}$ \\
\hline $\begin{array}{l}\text { Alternative 5 } \\
\text { (ALT5) }\end{array}$ & $\begin{array}{l}\text { 16 MW wind turbines, 1.2 MW hydro power plant (70.4\% RES } \\
\text { share) }\end{array}$ \\
\hline $\begin{array}{l}\text { Alternative 6 } \\
\text { (ALT6) }\end{array}$ & $\begin{array}{l}\text { Hydro power plant 1.2 MW, Biomass power plant 1 MW, Wind } \\
\text { power plant 26 MW, Solar power plant 23.6 MW, batteries 101 } \\
\text { MWh, converter 6.230 MW (100\% RES share) }\end{array}$ \\
\hline $\begin{array}{l}\text { Alternative 7 } \\
\text { (ALT7) }\end{array}$ & A combination of 2 and 4 alternatives. \\
\hline $\begin{array}{l}\text { Alternative 8 } \\
\text { (ALT8) }\end{array}$ & $\begin{array}{l}\text { 16 MW wind farm, 1.2 MW Hydro power plant (all production } \\
\text { sold to the grid) }\end{array}$ \\
\hline
\end{tabular}

In the second phase, it is necessary to define the criteria that will be used to evaluate the alternatives. For the purposes of this paper, the criteria available in Homer pro software will be used and their weights factors (priorities) are given in Table 5. The highest weight was given to the criterion Energy sold (0.280) and the lowest to fuel costs (0.094).

Table 5.: Criteria weights

\begin{tabular}{lc}
\hline Criteria & Weight \\
\hline $\mathbf{C}_{1}$ Investment & 0.207 \\
\hline $\mathbf{C}_{2}$ Energy price & 0.195 \\
\hline $\mathbf{C}_{3}$ OM costs & 0.100 \\
\hline $\mathbf{C}_{4}$ Operating cost & 0.123 \\
\hline $\mathbf{C}_{5}$ Fuel costs & 0.094 \\
\hline $\mathbf{C}_{6}$ Energy sold & 0.280 \\
\hline
\end{tabular}

After alternatives and criteria are defined Expert choice software is used to perform AHP methodology. First of all, the criteria were compared against the goal (Table 6). 
Table 6.: Comparison of criteria in relation to the goal

\begin{tabular}{lllllll}
\hline & $\mathbf{C}_{\mathbf{1}}$ & $\mathbf{C}_{\mathbf{2}}$ & $\mathbf{C}_{\mathbf{3}}$ & $\mathbf{C}_{\mathbf{4}}$ & $\mathbf{C}_{\mathbf{5}}$ & $\mathbf{C}_{\mathbf{6}}$ \\
\hline $\mathbf{C}_{\mathbf{1}}$ & 1 & 1 & 2 & 2 & 3 & $1 / 2$ \\
\hline $\mathbf{C}_{\mathbf{2}}$ & & 1 & 2 & 1 & 2 & 1 \\
\hline $\mathbf{C}_{\mathbf{3}}$ & & 1 & 1 & 1 & $1 / 3$ \\
\hline $\mathbf{C}_{\mathbf{4}}$ & & & 1 & 1 & $1 / 2$ \\
\hline $\mathbf{C}_{\mathbf{5}}$ & & & & 1 & $1 / 3$ \\
\hline $\mathbf{C}_{\mathbf{6}}$ & \multicolumn{4}{c}{} \\
\hline \multicolumn{4}{c}{ Inconsistency $\mathbf{0 . 0 2}$} \\
\hline
\end{tabular}

Then, a comparison of the defined RES alternatives against the criteria is performed. Comparison matrices are presented in Tables 7-12.

Table 7.: Comparison RES alternative to $\mathrm{C} 1$

\begin{tabular}{lllllllll}
\hline & ALT1 & ALT2 & ALT3 & ALT4 & ALT5 & ALT6 & ALT7 & ALT8 \\
\hline ALT1 & 1 & $1 / 5$ & $1 / 4$ & $1 / 6$ & $1 / 3$ & $1 / 3$ & $1 / 4$ & $1 / 3$ \\
\hline ALT2 & 1 & $1 / 3$ & $1 / 4$ & 3 & 4 & 4 & 4 \\
\hline ALT3 & & 1 & $1 / 4$ & 3 & 6 & 4 & 4 \\
\hline ALT4 & & & 1 & 5 & 7 & 5 & 5 \\
\hline ALT5 & & & & 1 & 5 & 1 & 1 \\
\hline ALT6 & & & & & 1 & $1 / 5$ & $1 / 5$ \\
\hline ALT7 & & & & & & 1 & 1 \\
\hline ALT8 & & & & & & & 1 \\
\hline & & & & & & \\
\hline
\end{tabular}

Table 8.: Comparison RES alternative to $\mathrm{C} 2$

\begin{tabular}{lllllllll}
\hline & ALT1 & ALT2 & ALT3 & ALT4 & ALT5 & ALT6 & ALT7 & ALT8 \\
\hline ALT1 & 1 & $1 / 6$ & $1 / 2$ & $1 / 5$ & $1 / 6$ & $1 / 3$ & $1 / 4$ & $1 / 6$ \\
\hline ALT2 & 1 & 4 & $1 / 3$ & $1 / 3$ & 5 & 1 & $1 / 3$ \\
\hline ALT3 & & 1 & $1 / 3$ & $1 / 5$ & 3 & $1 / 4$ & $1 / 4$ \\
\hline ALT4 & & & 1 & $1 / 2$ & 4 & 2 & $1 / 2$ \\
\hline ALT5 & & & & 1 & 4 & 2 & 1 \\
\hline ALT6 & & & & & 1 & $1 / 4$ & $1 / 5$ \\
\hline ALT7 & & & & & & 1 & $1 / 3$ \\
\hline ALT8 & & & & & & \\
\hline & & & & & & & \\
\hline
\end{tabular}

Table 9.: Comparison RES alternative to C3

\begin{tabular}{lllllllll}
\hline & ALT1 & ALT2 & ALT3 & ALT4 & ALT5 & ALT6 & ALT7 & ALT8 \\
\hline ALT1 & 1 & $1 / 4$ & $1 / 6$ & $1 / 8$ & $1 / 5$ & $1 / 2$ & $1 / 5$ & $1 / 7$ \\
\hline ALT2 & 1 & $1 / 5$ & $1 / 8$ & $1 / 4$ & 4 & 2 & $1 / 4$ \\
\hline ALT3 & & 1 & $1 / 2$ & 4 & 6 & 5 & 4 \\
\hline ALT4 & & & 1 & 5 & 7 & 5 & 6 \\
\hline ALT5 & & & & 1 & 7 & 4 & 1 \\
\hline ALT6 & & & & & 1 & $1 / 3$ & $1 / 4$ \\
\hline
\end{tabular}


Figure 2.: Rank alternatives

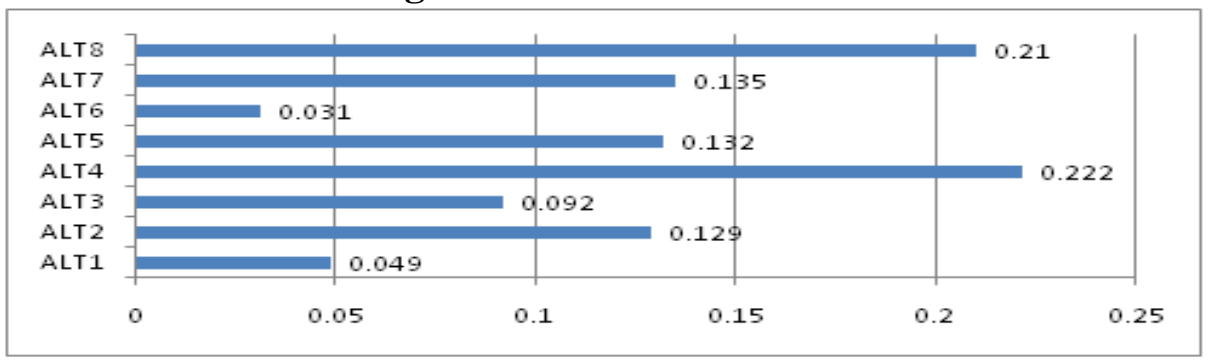

After the results obtained, a sensitivity analysis is performed. Sensitivity analysis should determine how changing the criterion's weight coefficient influences changes in the ranking of alternatives. Values from (Table 5) were taken as reference values. Minimal changes (increase or decrease) in the criterion's weight leading to the changes are considered.

Table 13.: Sensitivity analysis

\begin{tabular}{lllll}
\hline Scenario & Criteria & \multirow{2}{*}{ Reference values } & \multicolumn{2}{c}{ Minimal change } \\
\cline { 3 - 5 } & & & \multicolumn{2}{c}{+} \\
\hline Scenario 1 & Investment & $(0.207)$ & $/$ & 0.039 \\
\hline Scenario 2 & Energy price & $(0.195)$ & 0.128 & $/$ \\
\hline Scenario 3 & OM costs & $(0.100)$ & $/$ & 0.038 \\
\hline Scenario 4 & Operating cost & $(0.123)$ & $/$ & 0.053 \\
\hline Scenario 5 & Fuel costs & $(0.094)$ & 0.906 & $/$ \\
\hline Scenario 6 & Energy sold & $(0.280)$ & 0.032 & $/$ \\
\hline
\end{tabular}

Scenario 1. A decrease in the weight factor of the Investment criterion (-0.039) results in a change in the ranking of alternatives whereby alternative ALT4 (0.215) is ranked second and ALT8 (0.217) is ranked first. On the other hand, even in the case of an increase in the Investment weight factor to the maximum (1), there is no change in the ranking of the first-ranked alternative ALT4.

Scenario 2. By increasing the weight factor of the Energy price criterion to 0.323 , alternative ALT4 (0.214) becomes second ranked while ALT8 (0.215) takes the first position. By reducing the same criterion to a minimum (0), there is no change in the ranking of alternatives.

Scenario 3. Increasing the $O M$ criterion's weight coefficient to the maximum (1) does not lead to a change in the ranking of the top-ranked ALT4 alternative. Reducing the weighting factor to 0.048 alternative ALT8 (0.215) becomes the top priority by replacing ALT4 (0.214).

Scenario 4. Increasing the weighting factor of the Operating cost criterion to the maximum (1) does not lead to changes in the ranking of the top-ranked alternative ALT4. However, by decreasing to 0.07 , the 
ALT4 (0.213) alternative falls into second position while the ALT8 (0.214) becomes the first rank.

Scenario 5. Increasing the weight ratio of Fuel Costs to 1 equals the ranking of alternatives ALT1, ALT2, ALT4, ALT5, ALT7, ALT8 (0.159), while the significance of ALT3 and ALT6 is $(0.018 ; 0.029)$, respectively. Reducing the weight factor to a minimum does not lead to rank changes.

Scenario 6. Increasing the weight coefficient of the criterion Sold energy (0.312) alternative ALT8 (0.218) from the second goes to the first position by replacing ALT4 (0.217), while reducing the coefficient to a minimum (0) does not change the ranking of the first ranked alternative.

\section{CONCLUSIONS}

In this paper AHP method is employed to evaluate and rank 8 renewable energy alternatives suitable for municipality of Štrpce.

Based on the results obtained, ALT4 is the first ranked, with the highest importance given to the Energy sold criterion. In order to verify the results obtained, a sensitivity analysis was conducted. Only with a significant change of importance $(\geq 10 \%)$ changes occur in the ranking of strategies, which leads to the conclusion that the results obtained are reliable.

In future research, in addition to used economic criteria, other groups of criteria such as technical, environmental and socio-political should be analyzed. Also, more decision makers, ie stakeholders, need to be involved. This will make the decisions made more relevant.

\section{REFERENCES}

1. Ahmad, S. \& Tahar, RM. (2014). Selection of renewable energy sources for sustainable development of electricity generation system using analytic hierarchy process: a case of Malaysia. Renewable Energy, 63, 458-66.

2. Al Garni, H., Kassem, A., Awasthi, A., Komljenovic, D., \& AlHaddad, K. (2016). A multicriteria decision making approach for evaluating renewable power generation sources in Saudi Arabia, Sustainable Energy Technologies and Assessments, 16, 137-150.

3. Ali Khan, A., Shameem, M., Ranjan Kumar, R., Hussain, S., \& Yan, X.,(2019). Fuzzy AHP based prioritization and taxonomy of software process improvement success factors in global software development. Applied Soft Computing, 105648. 
4. Colak, E., Memisoglu, T., Gercek, Y., (2020).Optimal site selection for solar photovoltaic (PV) power plants using GIS and AHP: A case study of Malatya Province, Turkey, Renewable Energy, 149, 565-576.

5. Energy strategy of Kosovo* 2017-2026. Kosovo* Government. (2017).

6. Ervural, B.C., Zaim, S., Demirel, O., Aydin, Z., \& Delen, D. (2018). An ANP and fuzzy TOPSIS-based SWOT analysis for Turkey's energy planning, Renewable and Sustainable Energy Reviews. 82, 1538-1550.

7. Francés G.E., Marín-Quemada J.M., \& González E.S.M. (2013). RES and risk: renewable energy's contribution to energy security. Aportfolio-based approach. Renew Sustain Energy Rev, 26, 54959.

8. Haddad, B., Liazid, A., \& Ferreira, P. (2017). A multi-criteria approach to rank renewables for the Algerian electricity system, Renewable Energy, 107, 462-472.

9. International energy agency. (2017). Energy access outlook.

10. Konstantinos, I., Georgios, T., Garyfalos, A., (2019). A Decision Support System methodology for selecting wind farm installation locations using AHP and TOPSIS: Case study in Eastern Macedonia and Thrace region, Greece. Energy Policy, 132, 232246.

11. Lucas, J., Francés, G., \& González, E. (2016). Energy security and renewable energy deployment in the EU: Liaisons Dangereuses or Virtuous Circle? Renewable and Sustainable Energy Reviews. 62, 1032-1046.

12. Milovanović, Ž., (2019). Ranking projects risk-based by application of AHP methodology, Economic outlook, 21(1), 81101.

13. Milovanović, Ž., Todorović, M., Stojanović, M., (2018). Selection of plum varieties by ahp method, Economic outlook, 20(1), 79-91.

14. Municipality plan on energy efficiency 2016-2021. Municipality of Strpce. (2016).

15. Pasalari, H., Nabizadeh Nodehi, R., Hossein Mahvi, A., Yaghmaeian, K., Charrahi, Z., (2019). Landfill site selection using a hybrid system of AHP-Fuzzy in GIS environment: A case study in Shiraz city, Iran. MethodsX, 6, 1454-1466.

16. Ren, J. \& Sovacool, B. (2015). Prioritizing low-carbon energy sources to enhance China's energy security, Energy Conversion and Management, 92, 129-136. 
17. REN21. (2014). Renewables 2014 Global Status Report (Paris: REN21 Secretariat).

18. REN21. 2016. Renewables 2016 Global Status Report (Paris: REN21 Secretariat).

19. Saaty T.L. (1980). The Analytic Hierarchy Process: planning, priority setting, resource allocation. New York: McGraw-Hill.

20. Shahabi, R.S., Basiri M.H., Kahag M.R., \& Zonouzi S.A. (2014). An ANP SWOT approach for interdependency analysis and prioritizing the Iran's steels crap industry strategies, Resources Policy, 42, 18-26.

21. Stojčetović B., Mišić M., Šarkoćević, Ž., \& Marković, R. (2017). Energetska bezbednost opštine Štrpce - istraživanje stava lokalnog stanovništva, Energija, ekonomija, ekologija, (3-4), 190195.

22. Stojčetović, B., Nikolić Đ., Velinov V., Bogdanović D., (2016). Application of integrated strengths, weaknesses, opportunities, and threats and analytic hierarchy process methodology to renewable energy project selection in Serbia, Journal of renewable and sustainable energy, 8, 035906.

23. Stojčetović, B., Nikolić Đ., Živković, Ž., \& Bogdanović D. (2018). Swot-ahp method application to determine current energy situation and define strategies for energy security improvement, Thermal science, 23 (2b), 1-12.

24. U.S. Energy Information Administration. (2016). International energy outlook/IEO.

25. United nations. (2014). Decade of sustainable energy for all 2014-2024. 